\title{
The Use of Technology According to Christian Faith in The Era of Industrial Revolution 4.0.
}

\author{
Fransiskus Irwan Widjaja ${ }^{1}$, and Fredik Melkias Boiliu ${ }^{2}$
}

\author{
${ }^{1}$ STT Real Batam, Indonesia \\ ${ }^{2}$ Universitas Kristen Indonesia, Jakarta, Indonesia \\ irwanfiw@sttrealbatam.ac.id ${ }^{1}$,boiliufredik@gmail.com ${ }^{2}$
}

\begin{abstract}
This paper attempts to include the use of technology according to the Christian faith in the era of industrial revolution 4.0, which is directly proportional to the growth and the level of human needs for survival. Also, the rapid advancements observed at this time are in the aspect of information and technology, which is inseparable from the demands of communication, being the essence of human behaviour. Also, its concepts relate to the type of use, knowledge of tools and expertise, as well as the means through which it influences an individuals' ability to control and change environmental occurrences. Thus, the aim of technology is to facilitate human activities, and the recurring progress observed leads Christians to actually utilize it as a medium to build Christian faith. Furthermore, technology has existed through the time of human creation, found in Genesis 1: 27-28, which explained humans as the image and likeness of God (imago Dei). Therefore, the goal is embedded in their ability to explore the natural potentials necessary to meet personal needs. In addition, the verse underlies the birth of science and technology, with the existence of God's first mandate for the birth of grandchildren, the increasing number of world population, as well as the power over fish, birds and all animals. These verses bring to mind (ratio) the thoughts on how to rule the earth according to what Allah wants, and the knowledge to construct the technology is stated in Proverbs 1: 7a "Fear of God is the beginning of knowledge". In addition, the approach adopted in writing this paper is literature review and library research, thus, the outcome is expected to contribute to the academic world and also to the use of technology according to the Christian faith, in the era of industrial revolution 4.0.
\end{abstract}

Keywords: Technology, Christian Faith, Industrial Revolution 4.0

\section{INTRODUCTION}

The rapid worldwide development in the field of information and technology has influenced human civilization beyond expectations [1]. This influence is observed in the shifting social, cultural, economic, religious and political order, which requires a new balance between values, thoughts and the ways of life that applies to global and local contexts [2]. Technology as the application of organized knowledge to practical tasks, through the use of orderly systems and machines [3]. Also, encompass a branch of science concerned with industrial expertise or science related to the application of techniques in industries [4]. Furthermore, it is not possible for the era of globalization and modernization to be avoided by countries in the world, based on various aspects of life, and this refusal is tantamount to the occurrence of isolation from the international community [5]. This condition certainly complicates the propensity for a country to establish relations with others, and the inclusion of both has conferred positive and negative impacts on the Indonesian state [6].

Modernization is often challenged by traditional terms, as it signifies a change from the customary to modern society [7]. Thus, it is acknowledged as a process of change that involves communal renewal, in an attempt to obtain updated characteristics [9]. However, at the present 2021, it has become outdated by the emergence of paths, including instagram, whatsapp, and others applications [8]. This dimension to be very relative in nature, hence, what is currently perceived as modern is to be of traditional value in the future [10]. (2) The dimension of space, which tends to be very dependent on the people that embark on modernization, for example, the use of internet as a 
communication tool in Indonesia is a practice considered as luxurious and modern, although common and of traditionally value to the people of the United States [13]. According to a survey conducted by the Indonesian Internet Network Providers Association (APJII), it was shown that over half of the indigenous Indonesia population has been connected to the internet, which was estimated to be 132.7 million people, based on the survey performed throughout 2016 [11]. Furthermore, the total population alone is about 256.2 million, indicating a 51.8 percent increase, in contrast with the number recorded in 2014, thus, this investigation conducted by APJII only identified 88 million users [12].

The survey data proves the important role of the internet in technology impacts in human life, meaning that the 132.7 million Indonesians connected to the internet, includes Christians [14]. This is also based on the fact that technology controls humans, rather than the other way round [15].

\section{DISCUSSION}

\subsection{Technology}

Technology originated from the Greek word technologos or techne, which denotes expertise, and logos, meaning knowledge [18]. According to KBBI, Technology is the overall means to provide the goods needed for the survival and comfort of human existence [17].

Branch of science that deals with industry expertise and knowledge concerning the application of techniques [16]. In addition, it is the application of scientific concepts in problem solving or engineering applications, and technology is also interpreted as a collection of practical and applied science that is highly associated with engineering, industry, and others [19].

\subsection{Technology in the Old and New Testaments}

\subsubsection{Old Testament}

Technology is known to have existed through the era of human formation, as stipulated in Genesis 1: 2728 , where it was explained that creation ensued in the image and likeness of Allah (imago Dei). The development of understanding and technology is not limited to the time of creation, as it entails a continueous process, and a few examples in the Old Testament include:
- Prosperous. Allah ordered Noah to build a ship to save himself and the family from the destruction caused by the flood and the moral depravities of the world at that time. The skills portrayed involved Allah in the determination of the dimensions, and materials required. "So make for yourself an ark of cypress wood; make rooms in it and coat it with pitch inside and out. This is how you build it: the ark is to be three hundred cubits long, fifty cubits wide and thirty cubits high. Make a roof for it, leaving below the roof an opening one cubit. Put a door in the side, middle and top deck. "(Ge 6: 14-16).

\subsubsection{New Testament}

In the New Testament expressed several examples of technology, as follows:

- Synagogues (Mark 1:21), this technology was created to make it easier for people at that time to worship and teach the word of God.

- Boat (Matthew 4:22), this was created to help fishermen catch fish.

- The Temple (John 2:16) was designed as a place of worship.

- During the reign of Solomon, God punished Israel because of luxury, the sophistication of technology that had been misused by means of collecting foreign women, thus, Solomon fell into idolatry(1 Kings 11: 1-13).

\subsection{History of Technological Development}

Technology has evolved along with the changing times, and based on its personalized characteristics. Humans with respect to specific needs, in an attempt to facilitate the activities of daily life (Santoso, 2017). In addition, technology has passed through a very rapid phase of development in the industrial revolution, which is a term introduced by Fredrich Engels and Louis Auguste in mid-19th century. Furthermore Prasetyo and Soetopo (2021), and Marcella et al (2007) stated that this incidence has happened four times, as explained in the history provided below:

\subsubsection{Industrial Revolution 1.0}

The first industrial revolution originated in England at the end of the 18th century [21]. The invention of the steam engine by James Watt in the early 1800 s as the initiator, which subsequently spread throughout the European and American continents. This was, therefore, followed by other discoveries, in an 
attempt to overcome agricultural difficulties in Britain [22].

Therefore, subsequent developments instigated the replacement of human labor with mechanical power, which eventually led to an revolution in Britain, popularly known as industry 1.0. This lasted between 1750-1850, consequently making the country the number one economic engine in the 19th century and early 20th century. Therefore, further development continues, evidenced by massive changes in agriculture, manufacturing, mining, transportation and technology, which confer a profound impact on the social, economic and cultural conditions worldwide. Furthermore, London as the capital city was the center of modification, followed by the flow of money, and people, and the aim of improving their lives promoted the quest to meet up with the rapid economic demands [23]

\subsubsection{Industrial Revolution 2.0}

The 2.0 industrial revolution is a continuation of the 1.0, characterized by the emergence of power plants and internal combustion engines. Meanwhile, Prasetyo and Soetopo (2021) reported that its initiation occurred at the end of the 19th century, where machines powered by electricity were used for mass production activities. This discovery prompted the emergence of telephones, cars, airplanes, and others, responsible for the significant changes observed worldwide.

\subsubsection{Industrial Revolution 3.0}

Prasetyo and Soetopo (2017) reported the introduction of the third industrial revolution at in the early 1970s or the beginning of the 20th century, termed industry 3.0. This was initiated by the emergence and use of computers in automated manufacturing processes, hence known as the digital revolution, bridging the gap in time and space, as seen with the invention of the cars. Thus, the revolution 3.0, addressed as the digital age, was implicated in the present/real time, as it significantly changed the pattern of relations and communication in the contemporary society. Furthermore, business practices were also inevitably modified, in order to not be swallowed up by the times, although the third industrial revolution also possesses a side to watch out for [24]. Meanwhile, the advancement in technology enhanced the performance in factories and industrial machines over humans, and robots become a substitute, as sophisticated machines tend to possess a more productive capability that saves time. Consequently, the reduction in human labor is inevitable, as reproduction also ensures extraordinary power. A shortcoming of the internet and robot technology observed during the industrial revolution 3.0 was expressed in the absence of two-way interaction between humans and technology. Furthermore, scientists argue that the harmony of humans and technology through communication forms reciprocity between both. Thus, humans are increasingly facilitated towards overcoming problems or searching for personal needs.

\subsubsection{Industrial Revolution 4.0}

Yoga Hastyadi Widiartanto reported that the initiation of 4.0 industrial revolution occurred in the 21 st century, as the term first appeared in Germany in 2011. Meanwhile, at the 2015 World Economic Forum meeting, the German Chancellor, Angela Merkel, explained the capability of the system to integrate the online world with industrial production, while Slamet Rosyadi reported it as the fourth phase in the history of industrial revolution. Prof. Klaus Schwab, the German famous economist, founder and Executive Chair of the World Economic Forum (WEF), introduced the concept of Industry 4.0. in the book entitled "The Fourth Industrial Revolution",which explains the fundamental impact on human life and work. This, unlike the previous versions, possesses a wider scale, scope and complexity, and its current peak today, with the birth of digital technology has massively impacted on human life worldwide. Furthermore, the latest revolution pushes automated (instantaneous) systems in all activity processes, and the increasingly massive internet technology is identified to not only connects millions of people around the world, but has also serve as the basis for online trade and transportation transactions. In addition, the emergence of online shipping businesses, encompassing Gojek, Uber and Grab has successfully integrated human activities with information technology, subsequently leading to an increase in the economy [25].

Slamet Rosyadi explained the development of artificial intelligence, which entails the use of robots, drone technology, and cars that are able to run automatically, as well as the increase in biotechnology, social media applications, and nanotechnology, laying emphasis on the fundamental changes in the world and human life. The benefits of Industry 4.0 includes improvement in the speed and flexibility of production, enhanced service to customers, and augmented revenue. Therefore, the realization of these potential benefits positively impacts on a country's economy, and industry 4.0 offers numerous advantages, as well as challenges that must be faced. In addition, the problems faced by a 
country during the implementation include the emergence of resistance to changes in demographic and social aspects, instability in political conditions, limited resources, risk of natural disasters and the demand for applying environmentally friendly technologies.

\subsection{Positive and Negative Impacts of Technology}

The industrial revolution 4.0 plays a very big role in technological development, encompassing its positive impact on human life, and also its negative influence when misused.

\subsubsection{Positive Impact}

a. Opening job opportunities. It is possible to utilize this technology in the creation of jobs, for example by performing online businesses through social media.

b. Enhance the ease of work. An individual is now able to work from home, using a gadget to communicate with superiors, without visiting the office. However, the application of the engine and robot/algorithm is able to produce a lot of products in contrast to human labor.

c. Ensures easier communication. A person possesses the capacity to communicate with one another using a gadget in different places, e.g., release on the ground of homesick, through video calls and chatting.

\subsubsection{Negative Impact}

\section{a. The existence of Socio-Cultural Change in Society}

According to Ngafifi, socio-cultural change involves numerous aspects of life, encompassing art, science, technology, rules of organizational life, and philosophy. Therefore, revolution 4.0 is ascribed as one with an impact that occurred due to the progression, encompassing:

- The culture of other countries easily influences that of Indonesia, which is famous for its eastern traditions that have eventually become westernized, as expressed in the lifestyle of people. Examples include clothing and dress up, the nature of places to visit, for entertainment, and to shop, luxury goods, music, films, and gadget technology. Also, the internet also impacts the bad habits of smoking, consumption of alcohol and drugs, free sex and a sophisticated world.

- Changes observed in the form of interactions: In ancient times, humans tend to interact face-to-face, in order for the sense of kinship to become closer. This is contemporarily conducted via telephone, mobile phone, email, chat, Facebook, Yahoo! Messenger, Twitter, Internet Relay Chats, and various other advanced technologies. However, this results in a decline in an individuals' social relationship. For example on instances where there is an attitude of individualism, alongside egocentrism and disharmony in the family. Furthermore, the proper use of technology in communication, but in reality is adopted for negative things: e.g., addiction to internet, gadgets and games. This also involves the use of social media for hoax news, expressions of hatred and radicalism, infidelity, fraud, human trafficking, password theft, "cyber bullying", and data theft, and others.

- Believers become dependent on technology (technological slaves): The veneration of technology makes it an idol today, thus, wherever and whenever humans do not want to stop playing with gadgets, they tend to become busy alone with their gadgets, spending more time reading social media than the Bible. Meanwhile, there is no age limit on the use of technology, as both children and the elderly have been identified to use social media (Facebook, path, whatsapp, email, twitter, line and so on).

\subsection{The Bible's View of Technology}

Allah is the source of technology as he never hinders or closes all related developments, in association with salvation and Allah's purpose for humans and the world at large. The Bible says, "Let the wise hear and increase in knowledge, and also that the one who understands obtains consideration. In other words, there is a desire for humans to continue developing themselves, and also increase knowledge and understanding, indicating a disapproval of the intent to stay away from technology. This, therefore, stresses the need for awareness in the line of creating technology to the glory of Allah, because of his firm opposition in the line of any creation motivated by the greatness of self, group, or moral destruction of the nation.

Based on the explanation above, the Bible's view of technology are: 
- Humans were created in the image and likeness of Allah, and are thus given a mandate to manage the earth (Gen. 1: 27-18). Therefore, when they become Imago Dei, Allah provides the responsibility to further create technology, which must be accounted for.

- Allah taught the act of creating technology, for human salvation, which is clearly seen in the history of flood, where Noah was ordered to build a ship with the aim of saving him and the family from the destruction by flood, and the depravity of the world at that time. In addition, personal abilities signify that Allah intervened in determining the ship construction, alongside the dimensions of space, and every material (Gen 6: 14-16).

- Human-created variety ought to only be initiated for the glory of Allah, thus, there is a possibility that technology is able to spread the gospel throughout the world, and carry out the great commission (Matthew 28: 19-10).

- Technology is not meant to be idolized "because where your treasure is, there your heart will be also" (Matthew 6:21). Therefore, this also demands the need to master the technology, and not the technology that controls humans.

\section{CONCLUSION}

Humans have been mandated to carry out technological tasks, in order to connote blessings to others (Luke 4: 18-19) "The Spirit of the Lord is upon $\mathrm{Me}$, because $\mathrm{He}$ has anointed me to proclaim Good News to the poor; and he has sent me to announce release to the prisoners of war and recovery of sight to the blind, to send away free those who tyranny has crushed, to proclaim the year of acceptance with the Lord ". This means technology is not a goal but a tool, and humans have the right to do anything," but not everything is beneficial. "I have the right to do anything" but I will not be mastered by anything (1 Cor.6: 12). Albert Einstein reported that "Religion without science is blind and the inverse is lame.

Christian faith is the belief that precedes knowledge, which means "Believe in Allah first, the understanding of Him" based on the inability to provide proof through the humanistic limitations. Meanwhile, obtaining true knowledge demands that people first need to respect and fear God, thus, a fool does not appreciate the wisdom and also does not crave to be taught (Proverbs 1: 7). Therefore, living in the fear of Allah to honor Him helps in establishing an understanding on things that are difficult, and the source of science as well as technology is Allah. Furthermore, the Bible says "Let the wise hear and, followed by an increase in knowledge, as well as those with sound comprehension demands consideration (Proverbs 1: 5). Based on this verse it is seen that God actually wants continuity in the line of self-development, and an elevation in knowledge and understanding. This means the total embrace of science and technology. alongside the enthusiasm to foster continuity in further development.

\section{REFERENCES}

[1] Hamid, Sohana Abdul. "Pengaruh media massa terhadap perubahan sosial masyarakat." $e$ BANGI 11 (2016): 214-226.

[2] Marcella, Rita, et al. "The information needs and information-seeking behaviour of the users of the European Parliamentary Documentation Centre: A customer knowledge study." Journal of Documentation (2007).

[3] Nasution, Robby Darwis. "Effect of the Development of Communication Information Technology on Local Cultural ExistencePengaruh Perkembangan Teknologi Informasi Komunikasi Terhadap Eksistensi Budaya Lokal." Jurnal Penelitian Komunikasi dan Opini Publik 21.1: 123858.

[4] Nasution, Robby Darwis. "Pengaruh perkembangan teknologi informasi komunikasi terhadap eksistensi budaya lokal." Jurnal penelitian komunikasi dan opini publik 21.1 (2017): 30-42.

[5] Sidjabat, Binsen S. "MERETAS POLARISASI PENDIDIKAN KRISTIANI: Sebuah Pengantar tentang Arah Pendidikan Kristiani di Gereja, Akademia, dan Ruang Publik." Indonesian Journal of Theology 7.1 (2019): 7-24.

[6] Nuhamara, Daniel. "Pengutamaan Dimensi Karakter Dalam Pendidikan Agama Kristen." Jurnal Jaffray 16.1 (2021): 93-114.

[7] Prasetyo, Hoedi, and Wahyudi Sutopo. "Industri 4.0: Telaah Klasifikasi aspek dan arah perkembangan riset." J@ ti Undip: Jurnal Teknik Industri 13.1 (2021): 17-26.

[8] Santoso., 2017. Para Penggerak Revolusi. Laksana, Yogyakarta

[10] Setiawan, Daryanto. "Dampak perkembangan teknologi informasi dan komunikasi terhadap budaya." JURNAL SIMBOLIKA: Research and Learning in Communication Study 4.1 (2021): 6272.

[11] Sitorus, Merinda Maranatha, and Fredik Melkias Boiliu. "Kajian Perkembangan Teknologi 
Berdasarkan Pendidikan Agama Kristen." Biormatika: Jurnal ilmiah fakultas keguruan dan ilmu pendidikan 7.1 (2021): 110121.

[12] Komlos, John. "Shrinking in a growing economy? The mystery of physical stature during the industrial revolution." The Journal of Economic History 58.3 (1998): 779-802.

[13] Goldstone, Jack A. "Efflorescences and economic growth in world history: rethinking the" Rise of the West" and the Industrial Revolution." Journal of world history (2002): 323-389.

[14] Chapman, Stanley. Merchant enterprise in Britain: From the industrial revolution to World War I. Cambridge University Press, 1992.

[15] Taylor, Shirley, and Peter A. Todd. "Understanding information technology usage: A test of competing models." Information systems research 6.2 (1995): 144-176.

[16] Danneels, Erwin. "Disruptive technology reconsidered: A critique and research agenda." Journal of product innovation management 21.4 (2004): 246-258.

[17] Rogers, Donna L. "A paradigm shift: Technology integration for higher education in the new millennium." AACE Review (formerly AACE Journal) 1.13 (2000): 19-33.

[18] Oke, Adekunle, and Fatima Araujo Pereira Fernandes. "Innovations in teaching and learning: Exploring the perceptions of the education sector on the 4th industrial revolution (4IR)." Journal of Open Innovation: Technology, Market, and Complexity 6.2 (2020): 31.

[19] Fonseca, Luis Miguel. "Industry 4.0 and the digital society: concepts, dimensions and envisioned benefits." Proceedings of the international conference on business excellence. Vol. 12. No. 1. Sciendo, 2021.

[20] Ajmera, Puneeta, and Vineet Jain. "Modelling the barriers of Health 4.0-the fourth healthcare industrial revolution in India by TISM." Operations Management Research 12.3 (2019): 129-145.

[21] Trauth-Goik, Alexander. "Repudiating the fourth industrial revolution discourse: a new episteme of technological Progress." World Futures 77.1 (2021): 55-78.

[22] Skilton, Mark, and Felix Hovsepian. The 4th industrial revolution: Responding to the impact of artificial intelligence on business. Springer, 2017.

[23] Oliver, Willem H. "Teaching theology in the Fourth Industrial Revolution." HTS Teologiese Studies/Theological Studies 76.2 (2020): 11.

[24] Götz, Marta. "Attracting foreign direct investment in the era of digitally reshaped international production. The primer on the role of the investment policy and clusters-The case of Poland." Journal of East-West Business 26.2 (2020): 131-160.

[25] Doucet, Armand, et al. Teaching in the fourth industrial revolution: Standing at the precipice. Routledge, 2021.

[26] Wilis, R. A., \& Nurwulandari, A. (2020). The effect of E-Service Quality, E-Trust, Price and Brand Image Towards E-Satisfaction and Its Impact on E-Loyalty of Traveloka's Customer. Jurnal Ilmiah MEA (Manajemen, Ekonomi, \& Akuntansi), 4(3), 1061-1099. 